\title{
Sean McKinnon and Pilar Prieto The role of prosody and gesture in the perception of mock impoliteness
}

\begin{abstract}
Within the impoliteness literature, an important distinction has been made between genuine and mock (or non-genuine) impoliteness (Culpeper 1996, 2011; Bernal 2008, among others). Even though mock impoliteness has generally been analyzed within an impoliteness framework, recent proposals suggest that it is an essentially different pragmatic phenomenon that requires a continuous conversational evaluation (Haugh and Bousfield 2012). The present study had the goal of assessing the offline evaluation process of target genuine vs. mock impoliteness utterances, specifically the role the situational/ discourse contexts, as well as prosodic and gestural patterns, play in their interpretation. A total of 97 participants were either asked to rate the degree of impoliteness of target genuine and mock impoliteness utterances in isolation (Experiment 1), or to rate the same utterances preceded with a set of matched and mismatched situational/discourse contexts which favored either a genuine or a mock impoliteness interpretation (Experiment 2). The results of the two experiments show that (a) evaluations of intended mock impoliteness utterances generate more uncertainty in listeners than intended genuine impolite utterances; and (b) mock impoliteness evaluations are characterized by a more active use of gestural cues. These results provide evidence that mock impoliteness triggers a more complex evaluation procedure of a phenomenon that lies on the boundary between polite and impolite behavior.
\end{abstract}

Keywords: impoliteness, mock impoliteness, prosody, gestures, experimental pragmatics

DOI 10.1515/pr-2014-0009

\section{Introduction}

Shortly after Brown and Levinson (1987) released their groundbreaking work on politeness and the way politeness strategies are manifested in language,

Sean McKinnon, samckinn@indiana.edu

Pilar Prieto, pilar.prieto@upf.edu 
pragmatists were also left to conceptualize the opposite end of the politeness spectrum: impoliteness. Brown and Levinson's theory relies on the concept of "face"”, the self-image that we project to the public, and how politeness uses different strategies to mitigate the potential damage to the interlocutor's face, i.e., face-threatening acts, FTAs. It is through this framework that Culpeper (1996) theorized impoliteness, whose main goal, he claimed, is to damage the face of the interlocutor. Each of the politeness strategies outlined in Brown and Levinson (1987) have an opposing impoliteness strategy in Culpeper's (1996) original framework. For example, in relation to positive face, "the positive consistent self-image or 'personality' (crucially including the desire that this selfimage be appreciated and approved of) claimed by interactants" (Brown and Levinson 1987: 61), positive politeness strategies include jokes and using identity markers that increase in-group solidarity (Brown and Levinson 1987). According to Culpeper (1996) the opposing positive impoliteness strategies include the use of taboo words and name-calling.

During the development of impoliteness theory, the literature made a clear distinction between two types of impoliteness, namely genuine and mock (i.e., non-genuine) impoliteness. Genuine impoliteness has been described as a set of "communicative strategies designed to attack face, and thereby cause social conflict and disharmony" (Culpeper et al. 2003: 1546) and has been refined to take into consideration the interlocutor's evaluation of the genuinely impolite speech acts (Culpeper 2005). One of the more recent definitions of genuine impoliteness claims that impoliteness arises when there is a conflict between how one believes, expects or wants social organization to be and how another's behavior goes against that world-wide view (Culpeper 2010). Some examples of conventionalized genuine impoliteness formulae found in English include insults (e.g., 'you fucking piece of shit'), dismissals (e.g., 'go fuck off'), silencers (e.g., 'shut the fuck up') and negative expressives (e.g., 'go to hell') (Culpeper 2010).

Mock impoliteness has frequently been analyzed through a genuine impoliteness frame, in that mock impoliteness has been described as the suspension of the conditions, circumstances and evaluations that would cause a given utterance to be interpreted as genuine impoliteness, in favor of an interpretation that gives rise to social bonding (Culpeper 2011). For example, let us examine the use of the Mexican Spanish taboo word güey, 'idiot,' as cited in Mugford (2013):

A: ¿Qué vas a hacer mañana güey? 'what are you doing tomorrow güey?'

B: Trabajar güey 'working güey'

C: ¡En la noche! 'in the night!'

Mugford (2013: 110) 
Since the traditional semantic meaning of güey is 'idiot', in order to interpret the target utterance as mock impoliteness participants must realize that its semantic meaning should not be taken literally. As such, the truth condition of güey is suspended by the participants wishing to interpret it as mock impoliteness, hence creating bonding between these participants.

As Culpeper (2011: 208) puts it, mock impoliteness derives from "an understanding on the part of a participant that the contextual conditions that sustain genuine impoliteness do not apply”. Leech's (1983) Banter Principle, a strategy to convey politeness in which the interlocutor interprets untrue and impolite utterances as only being superficial in nature, has been used as a foundation for many conceptualizations of mock impoliteness. In his original work on impoliteness, Culpeper (1996) used this principle to argue that banter (or humorous insult) and mock impoliteness are one and the same, since both are only on the surface and not intended to cause any harm, but instead to create social bonding. This view was further expanded upon in Culpeper (2011: 207), when he stated that "the recontextualisation of impoliteness in socially opposite contexts creates socially opposite effects, namely affectionate, intimate bonds amongst individuals and the identity of that group". According to him, it is this absolute openness and vulnerability about the potential consequences of the interlocutor's interpretation going awry into being perceived as genuine impoliteness that is at the essence of mock impoliteness, and why it is commonly used as a social bonding tool.

Indeed, the literature has clearly shown that mock impoliteness is a powerful tool for social bonding and relationship building (Boxer and Cortés-Conde 1997; Bernal 2008; Haugh and Bousfield 2012, among many others). In this literature, the situational context (i.e., the mismatch between the use of impolite formulae and the presence of friendly relationships) have been highlighted as important factors in the determination of mock impoliteness, especially since both types of impoliteness often use the same formulae, e.g., "taboo" words (Stenström and Jörgensen 2008; Haugh and Bousfield 2012; Mugford 2013) and insults/abuse (Culpeper 2010; Haugh and Bousfield 2012).

Even though contextual factors have been highlighted as key factors in the interpretation of mock impoliteness, less emphasis has been placed on the potentially ambiguous grounds involved in the interpretation of mock impoliteness, i.e., the slippery slope into genuine impoliteness territory. In this regard, Culpeper (2010: 3236) suggested that the (im)politeness of an utterance should be determined by both semantics and pragmatics since "(im)politeness can be more inherent in a linguistic expression or can be more determined by context, but neither the expression nor the context guarantee an interpretation of (im)politeness". In their recent paper on mock impoliteness, Haugh and Bous- 
field (2012) examined the interactions of young men from Australia and Britain, and suggested that mock impoliteness needs to be evaluated outside of (im)politeness frameworks and explained in its own right. The authors proposed that mock impoliteness "involves evaluations of talk or conduct (emphasis ours) that are potentially open to evaluation as impolite by at least one of the participants in an interaction, and/or as non-impolite by at least two participants" (Haugh and Bousfield 2012: 1103). In their view, mock impoliteness is only achieved when both the speaker and the interlocutor, in a conversation involving only two people, or at least two participants in a conversation of three or more evaluate the utterance or behavior as such; this is to say that no action, behavior or utterance can inherently convey mock impoliteness, but rather that they must be interpreted by the participants in the interaction, as supportive of interpersonal connections. The evaluation process for recognizing non-genuine impoliteness in interaction involves a complex task of assessment of a multiple set of sociocultural, situational, and linguistic factors. In Haugh and Bousfield's proposal, the focus is on the evaluation of talk (speech) or conduct (gestures), as well as context, by the participants in the conversation for the interpretation of mock impoliteness. In this sense, they remarked that gestures such as laughter and smiling may be crucial, and even absolutely necessary, as additional signals to indicate that the impoliteness is not genuine, as in the following commentary about a jocular exchange between two Australian interlocutors:

Nathan's intonation in line 28 [oh, you're a nobhead] in delivering the insult does not provide any indication that he is framing it as jocular. However, careful examination of Nathan's facial expressions and head movements at this point in the interaction indicate that it was projected as non-serious. At the same time Danz is laughing (line 30), Nathan can be observed to fractionally tilt his head backwards and smile slightly (Haugh and Bousfield 2012: 1108).

Haugh and Bousfield's (2012) proposal opens the way for a more dynamic and interactional approach to mock impoliteness. Thus, mock impoliteness can be understood as potentially genuine impoliteness behavior that is continuously open to conversational evaluation as both potentially genuine impoliteness or potentially non-impolite and supportive behavior. If we find evidence that evaluations of mock impoliteness by listeners are (a) modulated by the listeners' sense that they are facing potentially impolite behavior; and (b) characterized by a more active use of prosodic and gestural cues signaling the speaker's intentions, then we will have motivation for a more thorough interactive model of the processing of mock impoliteness.

The overarching goal of the present study will be to experimentally investigate the role of situational and discourse context together with prosodic and 
gestural patterns in the offline evaluation of genuine vs. mock impoliteness utterances. For the design of the two rating experiments below, two main factors were systematically taken into account, namely, situational/discourse context, as well as prosodic and gestural signals. In Experiment 1, participants were presented with audio and video files of isolated target sentences that were produced in a mock impoliteness vs. genuine impoliteness situational context; the use of this specific task (see section 2.1.3 below) allowed us to simulate the experience of coming into a conversation without knowing the common ground and having to interpret an utterance as genuine or mock impoliteness. For each trial, they were asked to rate to what extent the speaker (a) was insulting (genuine impoliteness) and (b) was joking (mock impoliteness), on a 1 to 5 Likert scale. To assess how the situational and discourse context interact with prosodic and gestural cues during the interpretation of impoliteness, Experiment 2 provided participants with a discourse context that either matched up with the target utterance (e.g., genuinely impolite discourse context with a genuinely impolite utterance) or created a mismatch (e.g., genuinely impolite discourse context with a mock impolite utterance). For each trial, they were asked to rate on a 1 to 5 Likert scale the extent to which the speaker (a) was insulting (genuine impoliteness) and (b) was joking (mock impoliteness), as well as the degree of adequacy between the situational prompt and the target utterance.

Following the interactional approach to mock impoliteness, we expect to find an asymmetry between the evaluation procedures of mock vs. genuine impoliteness in the listener ratings obtained. First, we expect that the complex nature of mock impoliteness will surface in the impoliteness ratings obtained, in the sense that mock impoliteness cases will trigger more doubt in the listeners, causing them to be more resistant to a mock impoliteness interpretation than to a genuine impoliteness one. And second, we expect to find evidence that gestural cues will be more actively taken into account by listeners in their evaluations of intended mock impoliteness utterances than in their evaluations of intended genuine impoliteness utterances.

In general, this study can also contribute to assessing the prosodic and gestural patterns involved in the realization of genuine and mock impoliteness. Despite knowing that prosodic and gestural patterns are an important part of the linguistic input for speakers to produce their messages and convey their intentions, the role of prosody and gesture has not been thoroughly examined in the politeness literature. As Culpeper (2011: 146) notes, "remarkably, the bulk of research on politeness or impoliteness pays woefully little attention to the role of prosody". He identifies gestures as yet another area of that has been largely ignored in the impoliteness literature, as follows: "non-verbal cues such as gaze, facial expressions, body movements/gestures [...] and the spatial posi- 
tioning of the self play a key role in communication [...] yet it is still an area that receives relatively little attention in communication and pragmatic studies" (Culpeper 2011: 151). With respect to the prosodic cues of politeness, a relatively consistent finding points to an increase in the pitch range, which generally leads to a higher perception of politeness. It was first identified in Brown and Levinson (1987) as a possible way to increase perceived politeness and has subsequently been followed up in the literature. For example, an increase in peak height can lead to higher levels of perceived friendliness in Dutch and English (Chen et al. 2004); yet Nadeu and Prieto (2011) showed that in Catalan an increase in the final pitch height of yes-no questions led to more impoliteness ratings unless sentences were accompanied by a smiling face. Politeness can also be achieved through accommodation to the interlocutor's pitch range (Lin et al. 2006) and speech rate (Ofuka et al. 2000). As far as impoliteness is concerned, there are even fewer studies that address the possible role of prosody in the manifestation of impoliteness. Culpeper et al. (2003) attempted to explore this area by explaining how different types of impoliteness within his negative and positive impoliteness strategies could be manifested through prosody. For example, the positive impoliteness strategy of denying common ground or dissociating from the interlocutor can be achieved through the mimicry of the interlocutor's voice or not accommodating to the loudness of the conversation (i.e., the opposite strategy to prosodic accommodation to achieve politeness as shown in Lin et al. 2006 and Ofuka et al. 2000). Hidalgo Navarro (2009) echoes Culpeper by stating that elevating one's tone of voice can be seen as a violation of the Cooperation Principle (Grice 1975), thereby achieving genuine impoliteness. Finally, the use of tonal downsteps has been linked to genuine impoliteness to "convey a sense of extreme finality or closure” (Culpeper 2003: 1570).

\section{Experiment 1}

The goal of Experiment 1 was to assess the role that prosody and combined prosody/gestures play in the interpretation of genuine and mock impoliteness, without the inclusion of any discourse context to the utterance. Participants were asked to rate on a 5-point Likert scale on the extent to which a speaker was insulting (genuine impoliteness) and joking (mock impoliteness) with an interlocutor. 


\subsection{Methods}

\subsubsection{Participants}

A total of 47 native Catalan speakers (19 males and 28 females; 13 between $18-$ 24 years old, 16 between 25-34 years old, 16 between 35-54, 2 were 55 and older; 3 use Catalan less than $25 \%$ of the time in their daily lives, 5 use it between $25-50 \%, 10$ use it between $50-75 \%, 29$ use it more than $75 \%$ of the time) participated in this experiment.

\subsubsection{Audiovisual recordings and materials}

In order to investigate which gestural and prosodic patterns are representative of genuine vs. mock impoliteness in Catalan, we employed an oral Discourse Completion Task (henceforth oral DCT, Blum-Kulka et al. 1989; Billmyer and Varghese 2000; Félix-Brasdefer 2010) to obtain target utterances of both genuine and mock impoliteness. The oral DCT provides participants with a situational prompt to elicit a response or utterance that is the target of the investigation. A total of 6 native Catalan speakers ( 3 women and 3 men, mean age $=33$, std. deviation $=5.1$ ) were asked to participate in a series of oral DCTs to obtain production data to be used in the perception experiments. All participants were dominant in Catalan, as indicated on their self-report that Catalan is the language they most often use on a daily basis and feel most comfortable in expressing themselves. The oral DCT contained 5 discourse contexts leading to an interpretation of mock impoliteness and 5 leading to an interpretation of genuine impoliteness, along with 10 fillers for eliciting ironic and vocative utterances; all these contexts were randomized. For the mock and genuine impoliteness discourse contexts participants were asked to read a scenario containing key words that signaled to them that they should either feel angry or upset and want to insult the person in the scenario (genuine impoliteness) or that the person in the scenario was joking with the participant, causing the participant to want to joke back with them (mock impoliteness). Following Lampert and Ervin-Tripp's (2006) finding that both men and women are more likely to use wisecracks and teasing when their interlocutor is male, all the interlocutors in the discourse contexts were males so that participants were directing their utterances towards a male figure. Since taboo words and slurs are a common target for genuine and mock impoliteness exchanges, these words were used in both the mock and genuine impoliteness discourse contexts. Each pair of genuine and mock impoliteness exchanges used the same target sentence (e.g., 
vés-te'n a la merda, 'go to hell') so as to compare the prosodic and gestural cues of the two utterances. A sample oral DCT discourse context for each condition (genuine vs. mock impoliteness) is shown in (1). The complete list of the discourse contexts is provided in the Appendix.

(1) Sample discourse contexts used in the oral DCT (one for each impoliteness condition)

\section{A. Genuine impoliteness condition}

\section{Catalan}

Després d'un desastrós tall de cabell, estàs ben empipat amb el teu nou pentinat. El perruquer t'ha deixat només amb un dit de cabell. Quan arribes a casa, et mires al mirall i comences a riure perquè et sembla que ha quedat totalment ridícul i no hi ha maneres d'arreglar-ho. Aquesta nit et reuneixes en un restaurant amb el grup de pàdel del gimnàs. Hi ha persones que coneixes i d'altres que no has vist mai. Quan arribes veus que hi ha un noi, que sembla el graciós del grup, que comença a riure i et diu:

"Què, t'han passat el tallagespes pels cabells, avui?" i continua rient. Tu t'empipes molt.

Ara digue-li que se'n vagi a la merda.

\section{English translation}

After a disastrous haircut, you are very angry about your new hairstyle. The stylist left you with only a little bit of hair. When you arrive home, you look in the mirror and begin to laugh because it looks totally ridiculous and there is not a way to fix it. That night you are going to meet up with the gym paddle group at a restaurant. There are some people that you know and others that you have never seen before. When you arrive, you see a boy, who appears to be the funny guy of the group, start to laugh and he says to you:

"What, did a lawnmower cut your hair?" and he continues to laugh. You are very annoyed.

Now tell him to go to hell.

\section{B. Mock impoliteness condition}

\section{Catalan}

Després d'un desastrós tall de cabell, estàs ben empipat amb el teu nou pentinat. El perruquer t'ha deixat només amb un dit de cabell. Quan arribes a casa, et mires al mirall i comences a riure perquè et sembla que 
ha quedat totalment ridícul i no hi ha maneres d'arreglar-ho. Aquesta nit et reuneixes amb els teus millors amics i saps que els encantarà veure't amb aquest pentinat tan alternatiu. Quan arribes veus que en Pau comença a riure i et diu:

“Què, t'han passat el tallagespes pels cabells, avui?” i continua rient. $\mathrm{Tu}$ el contestes en to de broma i li dius que se'n vagi a la merda.

\section{English translation}

After a disastrous haircut, you are very angry about your new hairstyle. The stylist left you with only a little bit of hair. When you arrive home, you look in the mirror and begin to laugh because it looks totally ridiculous and there is not a way to fix it. That night you are going to meet up with your best friends and you know that they will love to see you with your new alternative haircut. When you arrive you see Pau start to laugh and he says to you:

"What, did a lawnmower cut your hair?" and he continues to laugh. You jokingly respond by telling him to go to hell.

As can be seen from (1), there are two main differences in the discourse contexts that trigger a genuine or mock impoliteness interpretation. First, in the genuine impoliteness discourse context the target to whom the participant says vés-te'n a la merda, 'go to hell', is someone who is not a close confident of the participant, i.e., they are not friends. This way when the interlocutor in the scenario says què, t'han passat el tallagespes pels cabells, avui?, 'what, did a lawnmower cut your hair?, the speaker can easily arrive at the conclusion that this person is insulting them and not joking around with them. According to Bousfield (2007), one of the ways to counter an impolite utterance is to respond with your own impolite utterance, and that is what we asked the participants to do. Conversely, in the mock impoliteness scenario the situation stays the same but instead of an unknown person commenting on your disastrous haircut it is your friend who is making the comment. Mock impoliteness frequently occurs amongst friends, so this change in the situational prompt helped the participants to view the situation in a different light. Secondly, to further help the participants arrive at the intended interpretation of the scenario, the contexts tell the participants how to feel. In the genuine impoliteness case, the participants are told that they are very annoyed by the stranger's comments, while in the mock impoliteness case the participants are instructed to respond to their friend by joking back with them.

The recordings were performed in a quiet room at Universitat Pompeu Fabra or at a quiet private residence, using a professional video camera and tape 
Table 1: Nuclear intonation patterns of the target 60 utterances, separated by condition (genuine vs. mock).

\begin{tabular}{lrlllll}
\hline Impoliteness & $\mathbf{H}+\mathbf{L}^{*} \mathbf{L} \%$ & $\mathbf{L}^{*} \mathbf{L} \%$ & $\mathbf{L}^{*} \mathbf{H L} \%$ & $\mathbf{L}+\mathbf{H}^{*} \mathbf{L} \%$ & $\mathbf{L}^{*} \mathbf{H} \%$ & $\mathbf{H}^{*} \mathbf{H} \%$ \\
\hline Genuine & $13(43 \%)$ & $15(50 \%)$ & 0 & 0 & $1(3 \%)$ & $1(3 \%)$ \\
Mock & $5(17 \%)$ & $19(63 \%)$ & $4(13 \%)$ & $1(3 \%)$ & $1(3 \%)$ & 0 \\
\hline
\end{tabular}

recorder. All participants were instructed to face the camera against a white background; the face and upper body of the participants were recorded. A total of 60 utterances were produced ( 6 participants $\times 2$ impoliteness conditions $\times 5$ discourse scenarios).

After the production data was obtained by the researchers, a quantitative analysis was performed to not only describe the possible trends seen in the data, but to also select exemplary candidates to be used in the perception experiments. The target utterances were prosodically analyzed according to the Cat_ToBI system (Prieto 2014) in Praat (Boersma and Weenink 2008). ${ }^{1}$ The video clips were also analyzed to identify any gestural cues that were present in the target utterances. The second author independently transcribed half of the data for prosodic and gestural cues, and the cases in which there was no agreement were discussed and agreed upon. A summary of these nuclear intonation patterns found in the data is presented in Table 1.

A repeated-measures ANOVA with intonation contour as the dependent variable (6 levels, one for each intonation pattern listed in Table 1) and the impoliteness condition as the independent variable (2 levels: genuine or mock) revealed that the intonation contours did not occur at significantly different proportions $(F(1,58)=1.659, p=0.203)$. Although there was not a significant difference between the two impoliteness conditions with the intonation contours, which may be due to the small sample size (6 speakers each producing

1 This framework is based on the Autosegmental-Metrical (AM) theory of intonational phonology (Pierrehumbert 1980; Beckman et al. 2005; among others). In theory it conceives intonation contours as combinations of relevant pitch movements associated with metrically strong positions (i.e., pitch accents) and relevant pitch movements associated with phrase boundaries (i.e., boundary tones). In Catalan, pitch accents can be monotonal (High, $\mathrm{H}^{\star}$, or Low, $\mathrm{L}^{\star}$ ) or bitonal $\left(\mathrm{H}+\mathrm{L}^{\star}, \mathrm{L}^{\star}+\mathrm{H}, \mathrm{L}+\mathrm{H}^{\star}\right.$ or $\left.\mathrm{L}+<\mathrm{H}^{\star}\right)$, with the asterisk indicating the association of that tone with the metrically strong syllable. Boundary tones can be also monotonal ( $\mathrm{L} \%$, !H \% or $\mathrm{H} \%$ ), bitonal (HL \%, LH \% and L!H \%) or tritonal (LHL \%). Together, the combination of the phrase's final pitch accent and the final boundary tone is considered the nuclear intonation configuration, which can carry specific pragmatic meanings in Catalan (Prieto, 2014). See Prieto (2014) for a good review of Catalan intonational phonology. 
5 intended genuine and 5 intended mock impoliteness utterances), we shall continue our discussion with the trends in the data.

For both genuine and mock impoliteness, the most common nuclear configuration employed was that of $\mathrm{L}^{\star} \mathrm{L} \%$ (15 out of 30 for genuine impoliteness; 19 out of 30 for mock impoliteness), a nuclear configuration which is commonly associated with broad focus statements (Prieto 2014). Furthermore, the second most commonly used nuclear intonation in both the mock and genuine impoliteness data was that of $\mathrm{H}+\mathrm{L}^{\star} \mathrm{L} \%$, which in Catalan can used for commands (Prieto 2014); however, this configuration was twice as frequent with the genuine impoliteness utterances than the mock impoliteness ones, indicating that there was a stronger tendency to use $\mathrm{H}+\mathrm{L}^{\star} \mathrm{L} \%$ with genuine impoliteness (13 out of 30 utterance) than with mock impoliteness ( 5 out of 30 utterances). Two female speakers used a nuclear configuration of $\mathrm{L}^{\star} \mathrm{HL} \%$ for two of five mock impoliteness utterances each, which is the configuration used with polite requests in Catalan (Prieto 2014); interestingly, these participants used this type of configuration to soften the use of taboo words (i.e., the semantics) of the target utterance. Figures 1-3 illustrate the intonational differences between mock and genuine impoliteness, showing the intonational patterns which have been found to be associated with genuine impoliteness $H+L^{\star} L \%$ (Figure 1) and with mock impoliteness $\mathrm{L}^{\star} \mathrm{HL} \%$ (Figure 3). An example of the broad focus intonation $L^{\star} L \%$, found in both conditions, is shown in Figure 2.

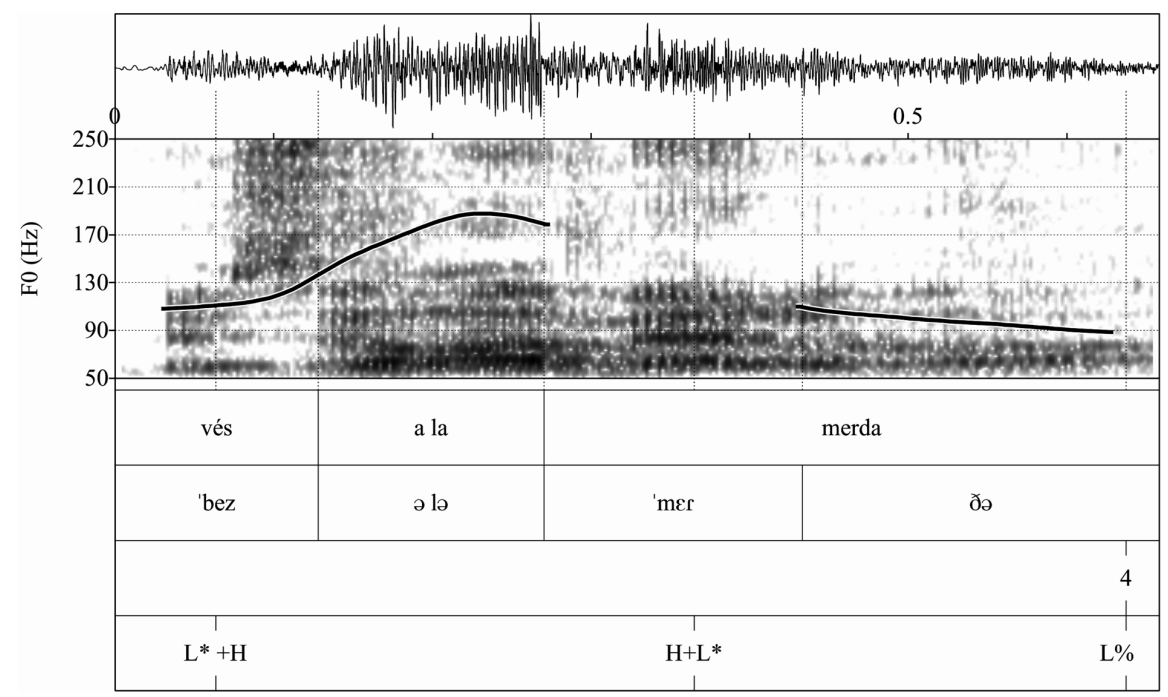

Figure 1: Waveform and F0 contour of the target of the target genuine impolite utterance vés a la merda, 'go to hell'. 


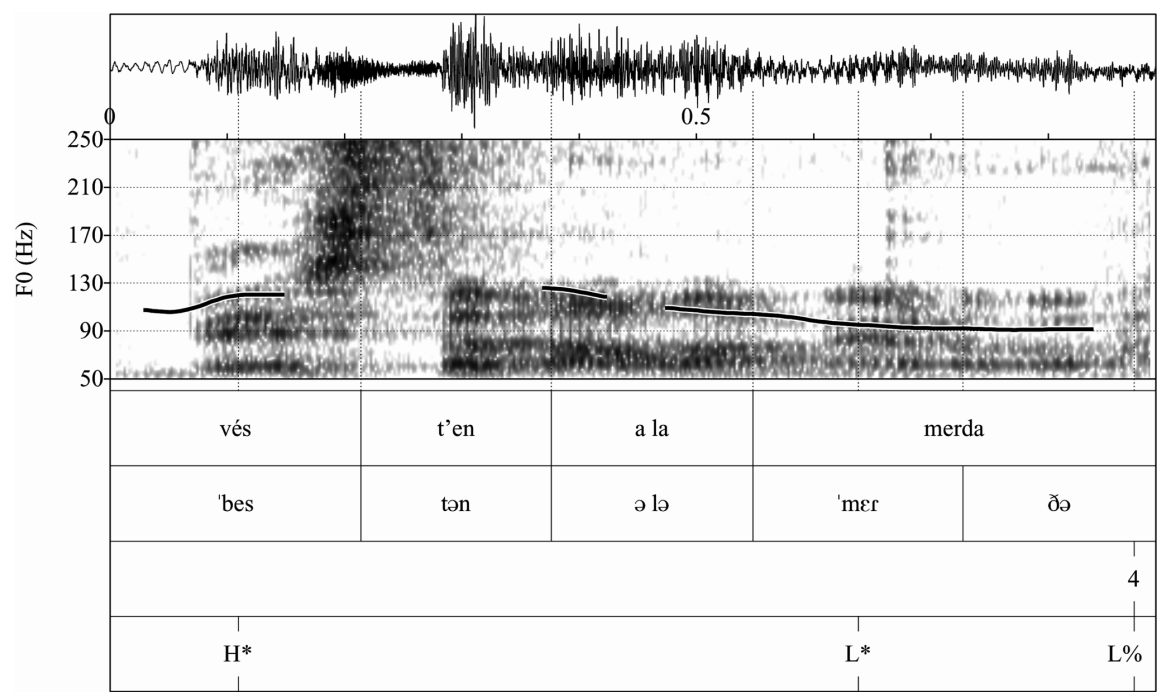

Figure 2: Waveform and F0 contour of the target of the target mock impolite utterance véste'n a la merda, 'go to hell'.

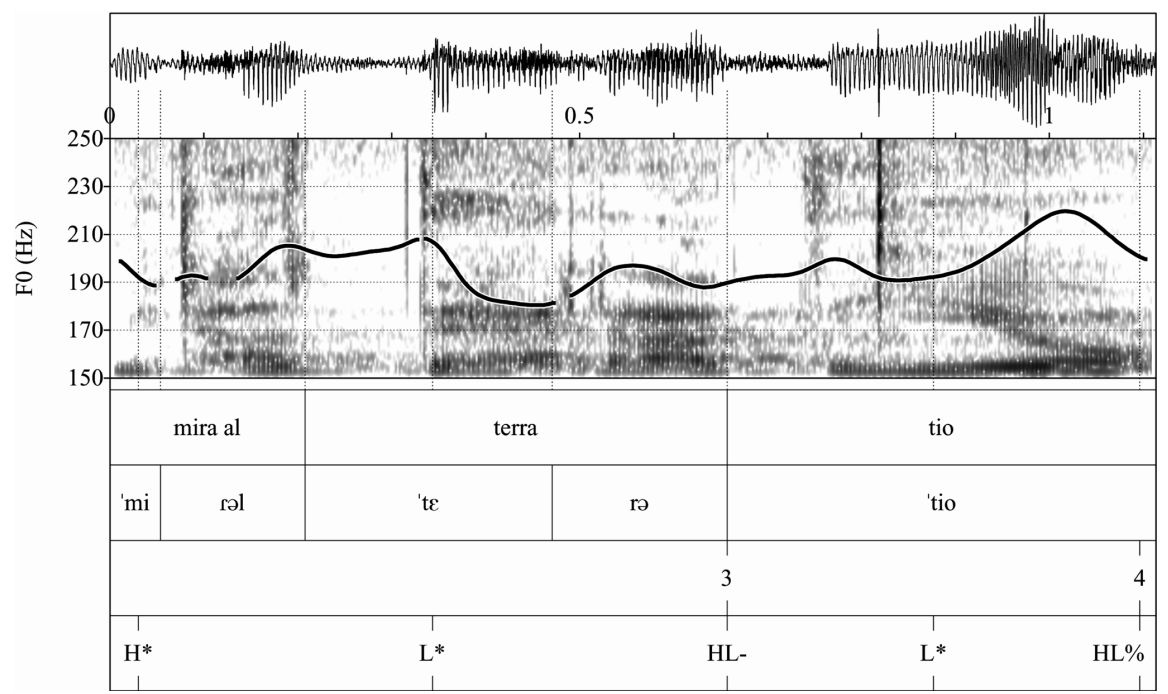

Figure 3: Waveform and F0 contour of the target of the target mock impolite utterance mira el terra, tio, 'look at the floor, dude'. 
Table 2: Mean of prosodic features of the target 60 utterances, separated by condition (genuine vs. mock).

\begin{tabular}{lcl}
\hline Prosodic Feature & Genuine Impoliteness & Mock Impoliteness \\
\hline Syllable duration & $17.10 \mathrm{~ms}(S D=3.26)$ & $18.39 \mathrm{~ms}(S D=4.31)$ \\
Pitch range & $101.34 \mathrm{~Hz}(S D=56.63)$ & $74.35 \mathrm{~Hz}(S D=41.35)$ \\
Highest peak of intensity & $76.90 \mathrm{~dB}(S D=5.52)$ & $73.52 \mathrm{~dB}(S D=3.93)$ \\
Intensity of whole utterance & $69.88 \mathrm{~dB}(S D=5.32)$ & $66.30 \mathrm{~dB}(S D=4.02)$ \\
\hline
\end{tabular}

Since the intonation patterns seem to only differ in some of the nuclear configurations, we now turn our attention to other prosodic features. We chose to analyze prosodic cues that have been previously related to the expression of anger (e.g., Murray and Arnott 1993) such as average syllable duration, pitch range (measured by subtracting the maximum FO value by the minimum F0 value for the nuclear pitch accents) and the highest peak of intensity in the target sentence, as well as the average intensity of the whole utterance. These findings are summarized in Table 2.

A series of independent samples t-test were run with each of these prosodic cues as the dependent variable, and with the impoliteness condition as the independent variable (2 levels: genuine or mock).

In general, results in Table 2 show that prosodic features associated with the genuine impoliteness data were those that have been associated with the expression of anger in the literature, which is not surprising given that anger has been linked before with genuine impoliteness (Culpeper et al. 2003). For example, the pitch range of the intonation contours was significantly different $(t(58)=2.07, p<0.05)$, with a higher pitch range observed in the genuine impoliteness condition utterances than in the mock impoliteness condition, following what has been said in the literature about wide pitch ranges characterizing anger (Murray and Arnott 1993). Finally, the highest peak of intensity for genuine impoliteness cases was higher than those for the mock impoliteness data $(t(58)=2.687, p=0.05)$; not surprisingly, loudness has been highlighted as one of the defining prosodic characteristics of anger (Culpeper et al. 2003; Hammerschmidt and Jürgens 2007). However, the difference between mock and genuine impoliteness was not significant for the syllable duration $(t(58)=$ $-1.28, p=0.20)$ or the average intensity for the whole utterance $(t(58)=2.89$, $p=0.07$ ).

Each target utterance was also analyzed for manual and facial gestures following McNeill (1992) (see also Prieto et al. 2013). Table 3 shows a quantitative summary of the appearance of the target manual and facial gestures. Fig- 
Table 3: Manual and facial gestures found in the 60 target utterances of genuine and mock impoliteness.

\begin{tabular}{lcc}
\hline Gesture & Genuine Impoliteness & Mock Impoliteness \\
\hline Head Shake & $8(27 \%)$ & $9(30 \%)$ \\
Head Nod & $10(33 \%)$ & $7(23 \%)$ \\
Furrowed Eyebrows & $15(50 \%)$ & $2(7 \%)$ \\
Raised Eyebrows & $8(27 \%)$ & $10(33 \%)$ \\
Smile & $3(10 \%)$ & $25(83 \%)$ \\
Manual PTC & $12(40 \%)$ & $8(27 \%)$ \\
Manual PTC Outward & $3(10 \%)$ & $1(3 \%)$ \\
Manual PTU/PTD & 0 & $5(17 \%)$ \\
\hline
\end{tabular}

${ }^{\mathrm{a}}$ Manual PTC $=$ RH (the right hand) \# B (palm open) \# PTC (palm toward center) \# moving from lower right periphery to upper right periphery.

${ }^{\mathrm{b}}$ Manual PTC Outward = RH (the right hand) \# B (palm open) \# PTC (palm toward center) \# moving from (extreme) lower right periphery to (extreme) upper right periphery and outward. ${ }^{c}$ Manual PTU/PTD = RH (the right hand) \# B (palm open) \# PTU (palm toward up) or PTD (palm toward down) \# moving from (extreme) lower right periphery to (extreme) right.

ures 4 and 5 show prototypical manual and facial gestures found for genuine impoliteness and mock impoliteness, respectively. As can be seen in the Table, the most common feature amongst the genuine impoliteness data was the furrowing of eyebrows and a palm towards the center gesture (Manual PTC; see Figure 4) that moves straight up vertically, level with the participant's head, before possibly moving straight forward (Manual PTC outward); interestingly, this gesture almost always starts at the beginning of a command word and reaches its gestural stroke at the accented syllable of the swear word. For mock impoliteness, the most consistent gestural feature among all the participants was a smile either throughout the utterance or at its end (see Figure 5). As far as gestural cues are concerned, a palm toward up or down that was raised slightly to be level with the participant's mid-torso (Manual PTU/PTD) was present in the mock impoliteness utterances. There was still the presence of the opened palm gesture as previously described in the genuine impoliteness data, but it was much more relaxed and fluid than the staccato movement seen with genuine impoliteness. A repeated-measures ANOVA with gestures as the dependent variable (8 levels, one for each gestural pattern listed in Table 3) and the impoliteness condition as the independent variable (2 levels: genuine or mock) revealed that the gestures did occur at significantly different proportions at the $p<0.05$ level $(F(1,124)=4.310, p=0.04)$.

From the production data obtained with the oral DCTs, 20 target utterances were chosen as stimuli for the perception experiments. The target utterances 


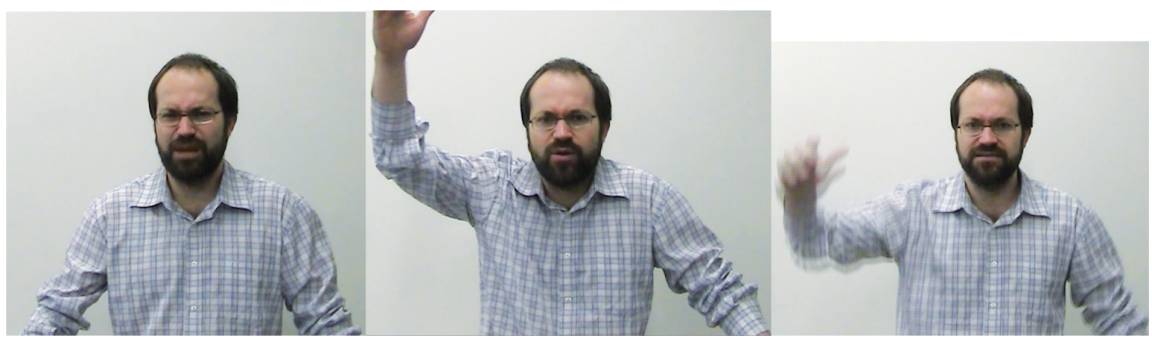

Target sentence: Hòstia puta, mira el cony de carrer quan condueixes, 'Goddammit, look at the fucking road when you're driving'.

Figure 4: Still video images of an example of genuine impoliteness (furrowed eyebrows and Manual PTC).

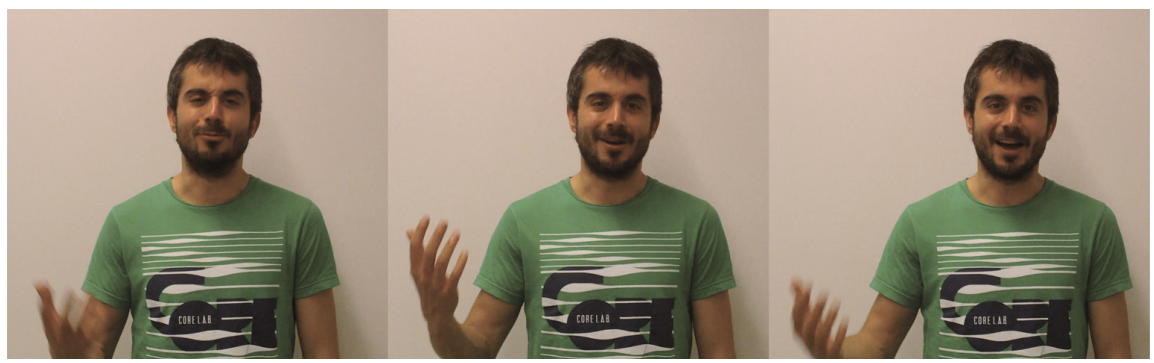

Target sentence: Vols callar d'una puta vegada?, 'Why don't you shut the fuck up?'.

Figure 5: Still video images of an example of mock impoliteness (smile and Manual PTU/ PTD).

were chosen to be prototypical examples of the overall trends observed in the data (e.g., $40 \%$ of the chosen genuine impoliteness utterances had a nuclear configuration of $\mathrm{H}+\mathrm{L}^{\star} \mathrm{L} \%$ ). Each participant had at least one mock and one genuine impoliteness utterance included in the perception experiment. Furthermore, there were no minimal pairs of utterances produced by the same speaker (e.g., if participant 1's genuine impoliteness utterance for discourse context 1 was included then their mock impoliteness utterance for that discourse context was not considered for inclusion). The target utterances were saved in an avi format for audiovisual (AV) and a .wav format for audio-only (AO).

\subsubsection{Procedure}

An online survey was created through surveygizmo.com for distribution via social media. The experiment was equally divided between two tasks: audio- 


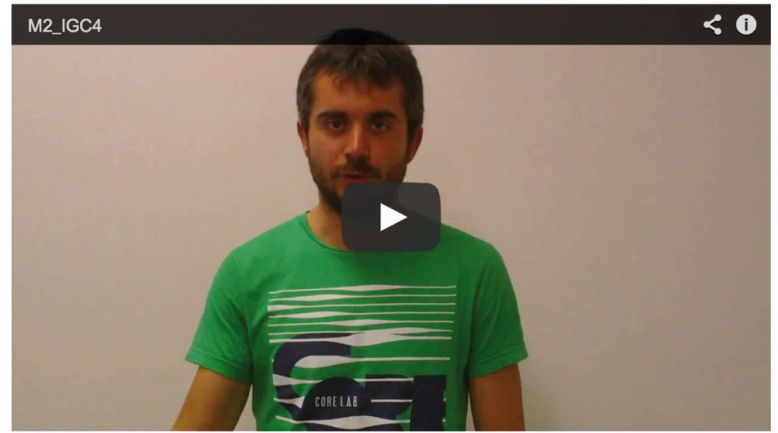

(Si vols tornar a veure la resposta has de clicar a L'EXTREM INFERIOR ESQUERRE DEL QUADRE)

71. Penses que el parlant està insultant el seu interlocutor? Contesta en una escala de l'1 al 5 . *

$\begin{array}{llll}\text { Totalment Força } \quad \text { Neutre Una mica } & \text { No l'està insultant }\end{array}$

72. Penses que el parlant està fent broma amb el seu interlocutor? Contesta en una escala de l'1 al 5. *

$\begin{array}{llll}\text { Totalment } & \text { Força } & \text { Neutre } & \text { Una mica }\end{array}$

Figure 6: Experiment $1 \mathrm{AV}$ condition.

only (AO) and audiovisual (AV). The AO task was the first one presented to the participants, followed by the AV task. For each stimulus, participants were first presented with the audio or audiovisual target utterance and asked to listen/ view it as many times as needed. For each utterance, they were then asked to rate on a 1 to 5 Likert scale the extent to which the speaker was insulting (genuine impoliteness) and joking (mock impoliteness): 1 "not insulting" (or for mock impoliteness, "not joking”), 2 "a little bit”, 3 "neutral”, 4 "strong”, 5 "totally". Figure 6 shows a screenshot from an AV stimulus.

Within each block the stimuli were randomized. At the end of the experiment, demographic, language use and personal use of swearing data were collected from each of the participants.

The experiment lasted between 15 to 20 minutes. We obtained a total of 1,880 responses for the $\mathrm{AO}$ and $\mathrm{AV}$ tasks ( 2 modalities $\times 20$ stimuli $\times 47$ participants). 


\subsubsection{Statistical analysis}

All responses obtained in Experiment 1 and 2 were analyzed through a Generalized Linear Mixed Model (GLMM) using IBM SPSS Statistics 19.0 (IBM Corporation, 2010). As Baayen et al. (2008) and Quené and van den Bergh (2008) point out, mixed-effects modeling offers considerable advantages over repeated measures ANOVA. Specifically for our data, they are suitable to analyze noncontinuous dependent variables, such as binomial and multinomial responses. On the other hand, we can control for both fixed and random factors at the same time (in our case, subject and item).

A new variable, "perceived impoliteness", was created by first reversing the Likert scale of mock impoliteness, so that it could be averaged with the genuine impoliteness scale. Theoretically speaking, we believe this move is justified because mock and genuine impoliteness are in opposition to one another, as evidenced by the description of the slippery slope between mock and genuine impoliteness (Culpeper, 2011; Haugh and Bousfield, 2012). By doing this, we were able to see a single measurement of impoliteness that on one end expressed more mock impoliteness (ratings of 1 and 2) and on the other end more genuine impoliteness (ratings of 4 and 5). The logic for doing this was that there was a significant negative correlation between the genuine impoliteness scale and the mock impoliteness scale $(r=-0.481, p<0.001)$, meaning that high values on the genuine impoliteness scale were significantly correlated with low values on the mock impoliteness scale, and vice versa. This variable was used as the dependent variable for the GLMM.

The two fixed factors for this experiment were speaker InTENTION (2 levels: the speaker produced either a genuine or mock impoliteness utterance) and MODALITY (2 levels: audio or audiovisual). The random factors in both experiments were a combination of subject and items, e.g., subject, his/her frequency and attitudes of "taboo" words, utterance speaker, DCT scenario.

\subsection{Results}

The GLMM analysis of the data revealed a main effect of speaker INTENTION $\left(F_{1}{ }_{1876}=954.127, p<0.001\right)$, with intended genuine impoliteness utterances (mean $=3.820$ ) being rated as higher in genuine impoliteness than the mock impoliteness utterances (mean $=2.626$ ). There was also a main effect for MODALITY $\left(F_{1} 1876=226.206, p<0.001\right)$, indicating that when listeners were presented with AO utterances they were rated higher in genuine impoliteness (mean = 3.510) than when presented with AV utterances (mean $=2.936$ ). 


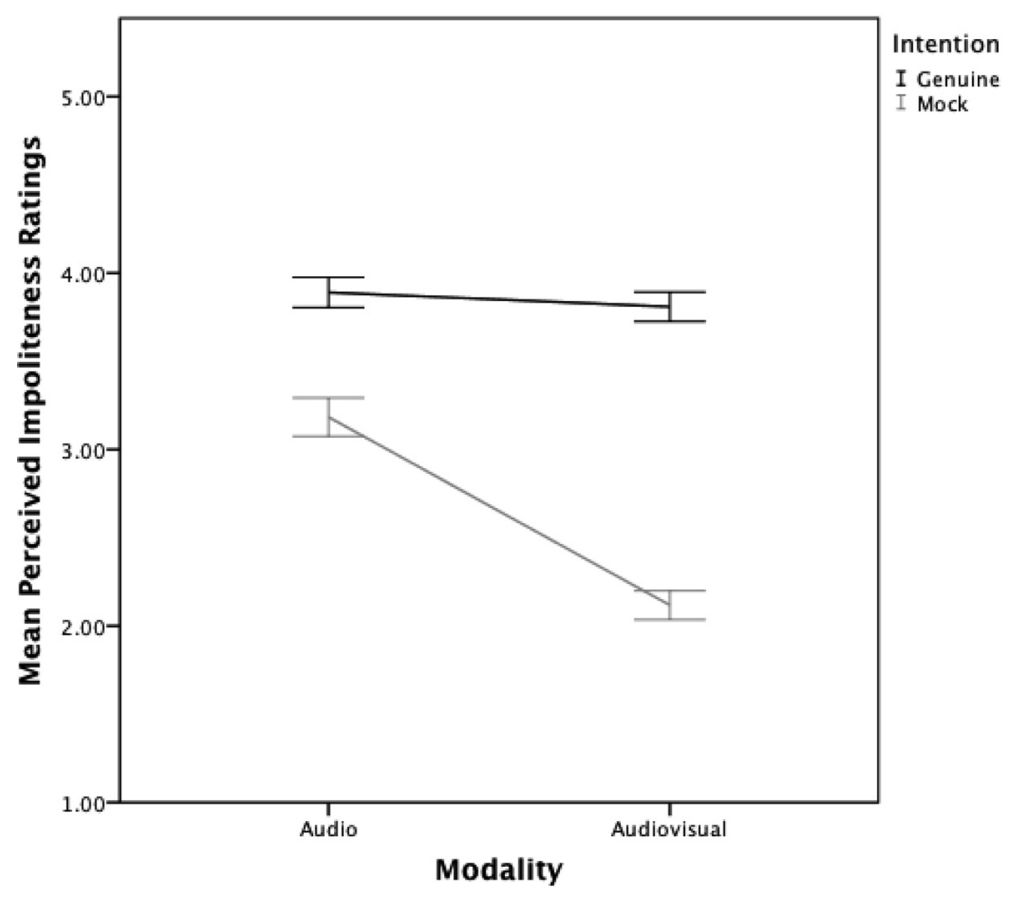

Error Bars: $95 \% \mathrm{Cl}$

Figure 7: Mean rating of perceived impoliteness as a function of INTENTION (genuine vs. mock impoliteness) and MODALITY (AO vs. AV).

Post-hoc analyses showed a significant interaction between MODALITY and INTENTION $\left(F_{1} 1876=166.912, p<0.001\right)$. Figure 7 shows the mean ratings of perceived impoliteness, ranging from 1 (more mock impoliteness) to 5 (more genuine impoliteness), as a function of INTENTION (genuine vs. mock impoliteness) and MODALITY (audio vs. audiovisual). The inspection of the data reveals an asymmetry between the evaluation of intended genuine vs. mock impoliteness, namely, while modality has no effect in the genuine impoliteness condition, it does in the mock impoliteness condition, in the sense that AV presentation of the utterances allow listeners to more easily detect the intended mock impoliteness.

\subsection{Discussion}

Summarizing the results of Experiment 1, Catalan listeners are able to perceive a difference between intended genuine and mock impoliteness utterances in 
the $\mathrm{AO}\left(t_{1876}=7.248, p<0.001\right)$ and $\mathrm{AV}$ conditions $\left(t_{1876}=16.540, p<0.001\right)$, even without a discourse context being provided to them.

The other interesting result is the difference between the identification of the two types of impoliteness based on modality. For genuine impoliteness, there was no significant difference between the two modalities, i.e., listeners easily detect genuine impoliteness from both an $\mathrm{AO}$ or an $\mathrm{AV}$ presentation. In the case of $\mathrm{AO}$, clear identification is due to prosodic cues that were mentioned before and that are associated with anger, e.g., wider pitch range and intensity peaks (see Table 2). By contrast, for mock impoliteness there was a significant difference for modality, with the AV presentations being rated almost a full point towards more mock impoliteness than AO (2.1 vs. 3.1, respectively). This demonstrates that gestural cues are an important component in the evaluation of mock impoliteness.

In sum, the results of Experiment 1 demonstrate that listeners are sensitive to prosodic and gestural cues in their evaluation of genuine and mock impoliteness. Moreover, the results have shown an asymmetry between the assessments of genuine and mock impoliteness utterances in the sense that exposure to the speakers' gestural patterns have allowed listeners to more accurately assess the intended mock impoliteness. Faced with a complex pragmatic phenomenon that can be interpreted as potentially impolite behavior, listeners make a strong use of gestural cues to detect mock impoliteness.

However, as pointed out before, discourse context is an essential component in the identification of the two types of impoliteness. Experiment 2 will analyze the interaction between discourse context and the prosodic and gestural patterns of the target utterances in the interpretation of genuine and mock impoliteness.

\section{Experiment 2}

The goal of experiment 2 was to assess the interplay of discourse context, prosody and gesture in the interpretation of genuine and mock impoliteness. The experiment followed the same format as Experiment 1, but with another level, MATCHING, being added: match vs. mismatch discourse context. In the matching condition, the production data was paired with its corresponding discourse context, i.e., the one that was used to obtain the utterance, while in the mismatch condition, discourse context and production data were incongruent, e.g., a genuine impoliteness prompt was used with its mock impoliteness counterpart, and conversely a mock impoliteness prompt was used with this genuine politeness counterpart. 


\subsection{Methods}

\subsubsection{Participants}

A total of 50 native Catalan speakers (21 males and 29 females; 10 between 1824 years old, 6 between 25-34 years old, 25 between 35-54, 9 were 55 and older) participated in this experiment. As for Catalan dominance, 1 used Catalan less than $25 \%$ of the time in their daily lives, 2 used it between 25-50\%, 11 used it between $50-75 \%$, and 36 used it more than $75 \%$ of the time.

\subsubsection{Audiovisual recordings and materials}

The same audiovisual materials used in Experiment $1(N=20)$ were used in Experiment 2 (see section 2.1.2.). Just as in Experiment 1, there were no minimal pairs of sentences produced by the same speaker used in the perception experiment.

The target 20 utterances were matched (and mismatched) with the 10 discourse contexts scenarios used for the oral DCTs (see the Appendix). Thus the total amount of items included in the experiment was 40 ( 5 scenarios $\times 2$ politeness conditions $\times 2$ modality conditions $\times 2$ matching conditions).

\subsubsection{Procedure}

In order to keep the time that it took to do experiment 2 the same as experiment 1 (since the addition of asking participants to read a short discourse context before listening/watching the target utterance would require more time to complete) experiment 2 was divided into two lists, list A and list B; both lists contained 10 audio utterances and 10 audiovisual utterances and they were equally divided between genuine and mock impoliteness utterances. There was no significant difference between the two lists $(p=0.3)$. In order to avoid learning effects, the presentation format was the same as experiment 1 in that the AO block was presented before the AV block. Each list contained an equal amount of matched vs. mismatched contexts.

Participants were asked to read the target discourse context before listening/watching the AO or AV stimulus. Key sentences that signaled the genuine or mock impoliteness of the discourse context were in bold so that participants could easily appreciate the type of impoliteness the discourse context was triggering. In addition to having to rate both the extent to which the speaker was 


\begin{abstract}
Després de llegir el següent context discursiu, escolta la frase tantes vegades com sigui necessari i contesta les preguntes següents.
El millor amic de la Marta, en Lluís, l'ha vingud a buscar a la feina i la porta a casa després d'un llarg dia. El trànsit va molt lent i s'han trobat un embús. Senten moltes botzines sonant i elsestà agafant mal de cap. Amb el seu amic sempre fa broma perquè condueix de forma molt agressiva. De sobte, veuen un forat a l'embús i en Lluís talla bruscament el cotxe de l'esquerra i arrenca a córrer, passant el semàfor gairebé en vermell.
\end{abstract}

La Marta li diu:

Escolta l'àudio següent tantes vegades com sigui necessari i després respon les següents preguntes.

- 00:00 00:01 -

23. Penses que el parlant està insultant el seu interlocutor? Contesta en una escala de l'1 al 5 . *

$\begin{array}{llll}\text { No l'està insultant } \quad \text { Una mica } & \text { Neutre } & \text { Força } & \text { Totalment }\end{array}$

24. Penses que el parlant està fent broma amb el seu interlocutor? Contesta en una escala de l'1 al 5. *

$\begin{array}{llll}\text { No està fent broma } & \text { Una mica } & \text { Neutre } & \text { Força }\end{array}$

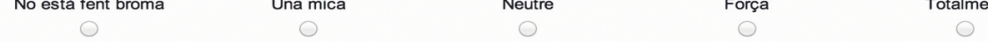

25. Valora de l'1 al 5 si creus que la manera de pronunciar la frase de la Marta encaixa amb la situació en què es produeix. *

No encaixa gens No gaire Dubto Encaixa força bé Encaixa perfectament

Figure 8: Experiment $2 \mathrm{AO}$ condition.

insulting or joking, the participants also had to rate on a 1 to 5 Likert scale the adequacy between discourse context and target utterance (1 being no encaixa gens ,'does not fit at all,' to 5 encaixa perfectament, 'fits perfectly').

The experiment lasted between 15-20 minutes. We obtained a total of 1,000 responses for the $\mathrm{AO}$ and $\mathrm{AV}$ tasks ( 2 modalities $\times 10$ stimuli $\times 50$ participants). Figure 8 displays an $\mathrm{AO}$ screenshot.

\title{
3.1.4 Statistical analysis
}

A Generalized Linear Mixed Model (GLMM) was employed in IBM SPSS 20.0 (IBM Corporation, 2011) for the statistical analysis. As with Experiment 1, the first dependent variable to be analyzed was the average "perceived impoliteness". The second dependent variable was the adequacy ratings of a given utterance, in relation to its discourse context. The two fixed factors for experiment 2 were INTENTION and MODALITY, in addition to discourse context MATCHING (match vs. mismatch). The random factors in this experiment were the same as experiment 1, e.g., subject, his/her frequency and attitudes of "taboo" words, utterance speaker, DCT scenario. 


\subsection{Results}

\subsubsection{Perceived impoliteness ratings}

The GLMM analysis revealed a main effect for INTENTION $\left(F_{11012}=155.582\right.$, $p<0.001)$ and for MODALITY $\left(F_{1} 1012=73.775, p<0.001\right)$, but not for MATCHING $\left(F_{11012}=1.113, p=0.292\right)$. There was a significant interaction between MODALITY $\times$ INTENTION $\left(F_{11012}=29.357, p<0.001\right)$ and INTENTION $\times$ MATCHING $\left(F_{11012}=\right.$ $148.821, p<0.001)$, but not for MODALITY $\times$ MATCHING $\left(F_{11012}=2.506, p=0.114\right)$. There was no significant 3-way interaction between MODALITY, INTENTION and MATCHING, although it was close to being significant $\left(F_{1012}=3.393, p=0.066\right)$.

Figure 9 shows the mean rating of perceived impoliteness. On the one hand, the matching condition replicates the overall same pattern observed in Experiment 1, that is, listeners are able to perceive a difference between the intended genuine and mock impoliteness when presented with AO $\left(t_{1012}=9.725\right.$, $p<0.001)$ or AV utterances $\left(t_{1012}=14.986 p<0.001\right)$. There was an effect of

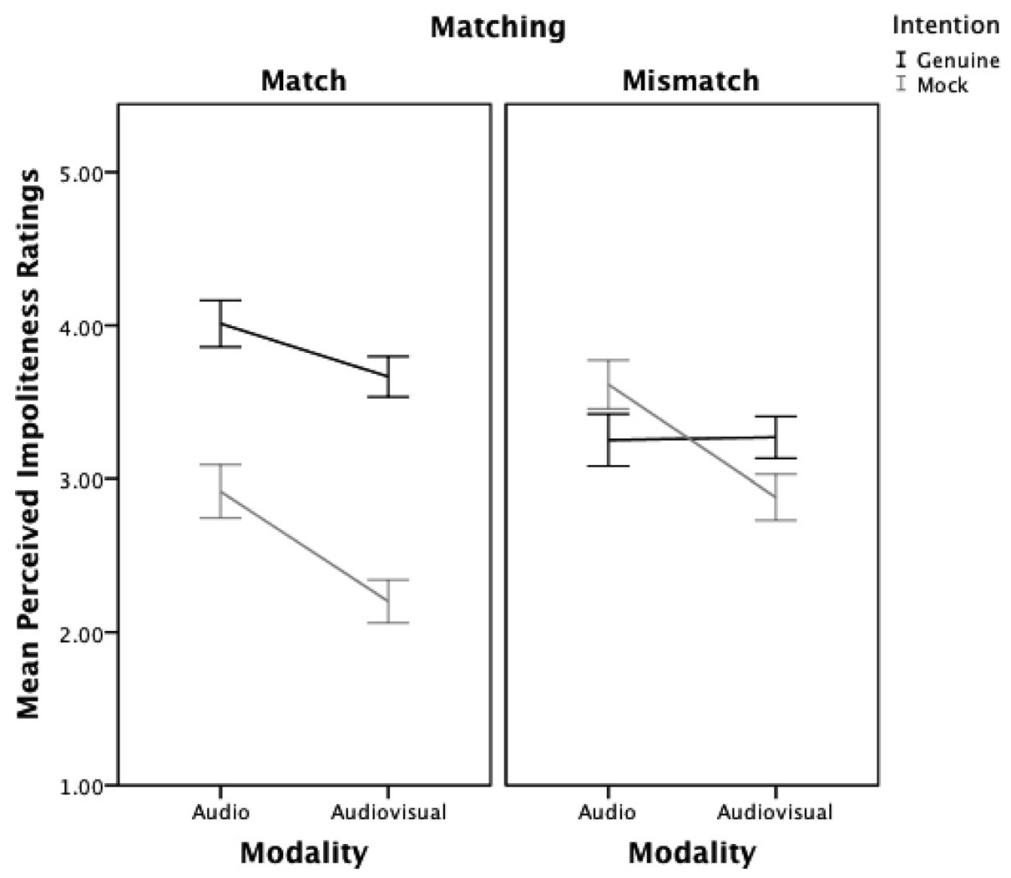

Error Bars: $95 \% \mathrm{Cl}$

Figure 9: Mean rating of perceived impoliteness as a function of INTENTION (genuine vs. mock impoliteness), MODALITY (AO vs. AV) and MATCHING (match vs. mismatch). 
modality in the detection of genuine impoliteness ( $\left.t_{1012}=2.295, p<0.025\right)$, with $\mathrm{AV}$ being rated as slightly less genuinely impolite than AO. As with experiment 1, gestural cues helped participants more easily identify mock impoliteness than with audio only $\left(t_{1012}=7.638, p<0.001\right)$.

As expected, for the mismatched materials the intended genuine impoliteness utterances were perceived to be less impolite than the utterances in the match condition $\left(t_{1012}=6.435, p<0.001\right.$ for AO; $t_{1012}=4.518, p<0.001$ for $\mathrm{AV})$, i.e., less genuinely impolite. Similarly, the intended mock impoliteness utterances were rated as more genuinely impolite than their match counterparts $\left(t_{1012}=6.470, p<0.001\right.$ for AO; $t_{1012}=6.965, p<0.001$ for AV), i.e., less mock impoliteness. Interestingly, in the intended mock impoliteness case we find an effect of AV utterances being rated as more mock impolite than the AO.

In sum, the results in this subsection show: (a) that the presence of an incongruent discourse context significantly affects the rating of the utterances; and (b) that the gestural patterns accessible in the AV condition significantly affect the ratings of the intended mock impoliteness utterances.

\subsubsection{Adequacy Ratings}

The GLMM analysis of the adequacy ratings revealed a main effect for MATCHING $\left(F_{1} 1_{1012}=22.482, p<0.001\right)$, as well as a significant interaction between MATCHING $\times$ INTENTION $\left(F_{11012}=10.281, p=0.001\right)$ and MATCHING $\times$ INTENTION $\times$ MODALITY $\left(F_{11012}=5.514, p=0.019\right)$. Figure 10 provides a summary for these findings.

The results in Figure 10 show that the means for all the possible combinations in the mismatch condition were somewhere between 3 (dubto, 'I doubt') to 4 (encaixa força bé, 'it fits quite well'). So even though both the adequacy ratings for both genuine impoliteness and mock impoliteness were lower in the mismatch condition than in the match condition, the participants still rated these utterances as acceptable fits with the mismatched discourse context. Interestingly, there was a significant difference between the adequacy ratings of the intended mock impoliteness utterances based on modality in the matched condition $\left(t_{1012}=3.172, p<0.005\right)$, showing that the addition of gestural leads to higher adequacy ratings. This again indicates that the addition of gestural cues not only helps participants arrive at a mock impoliteness interpretation of intended mock impoliteness utterances, but they also feel that the utterance fits more with a discourse context when there are gestures. 


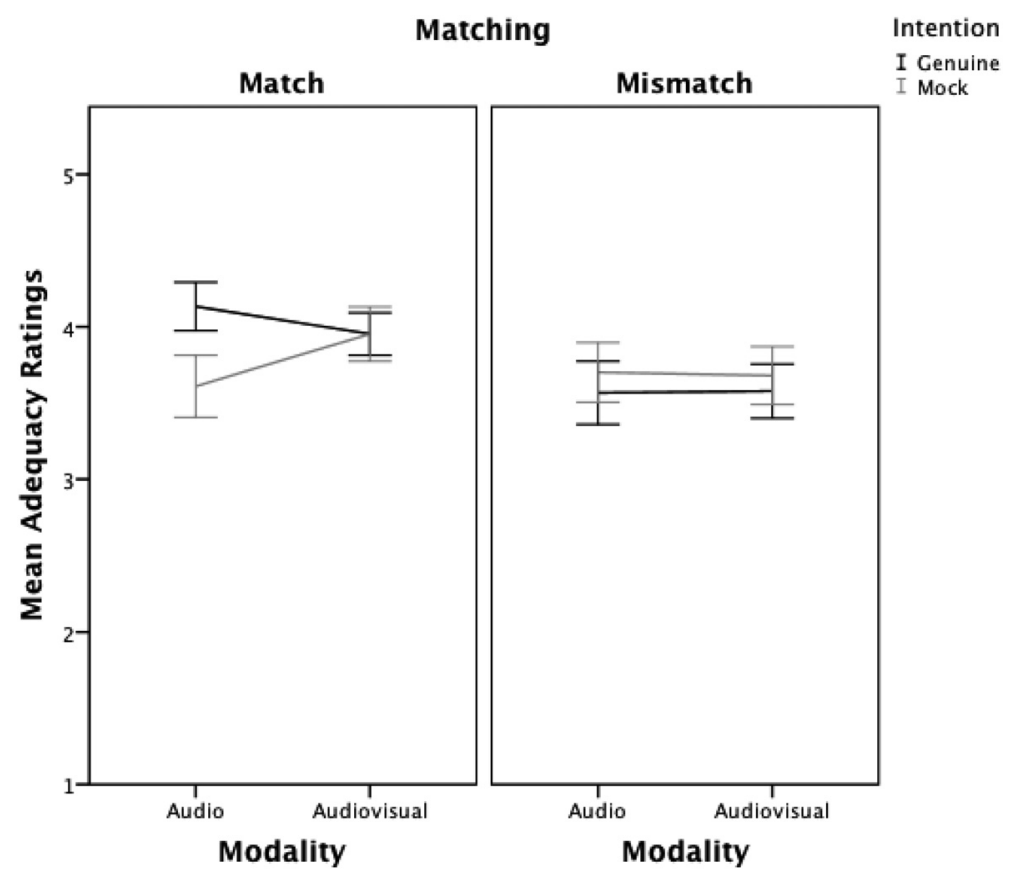

Error Bars: $95 \% \mathrm{Cl}$

Figure 10: Mean ratings of adequacy as a function of INTENTION (genuine vs. mock impoliteness), MODAlity (audio vs. audiovisual) and MATCHING (match vs. mismatch).

\subsection{Discussion}

Summarizing the results of Experiment 2, the match condition results were similar to the ones found in Experiment 1 in revealing an asymmetry between the evaluation of genuine vs. mock impoliteness. When listeners were not provided with a discourse context (Experiment 1) the intended genuine impoliteness utterances' means were 3.9 for AO and 3.8 for AV, while when they were provided with a matched discourse context the mean ratings were 4.0 for AO and 3.7 for $\mathrm{AV}$; again, the prosodic cues associated with anger were enough for participants to arrive at the intended genuine impoliteness interpretation. For mock impoliteness the mean ratings in Experiment 1 were 3.1 for $\mathrm{AO}$ and 2.1 for $\mathrm{AV}$, while when a matched discourse context was provided the mean ratings were 2.9 for $\mathrm{AO}$ and 2.2 for $\mathrm{AV}$. This again shows that the access to gestural information is important in the interpretation of the intended mock impoliteness utterances. 
Moreover, the results of Experiment 2 have shown that Catalan listeners are sensitive to mismatches between audio(visual) utterances and previous situational/discourse context, although they accept these pairs as naturally occurring. As expected, mismatches produced ratings that indicated a perception of a higher degree of impoliteness for the intended mock impoliteness utterances, and conversely, a lower degree of impoliteness for the intended genuine impoliteness utterances. Crucially, we again find an asymmetry between the evaluations of mock vs. genuine impoliteness. While for the intended genuine impoliteness cases there was no difference between the AO and AV presentations (the utterances were rated with a mean of 3.3), the intended mock impoliteness cases were considered to be more non-impolite and joking when presented in $\mathrm{AV}$ format, i.e. the mean ratings were 3.6 (intended mock impoliteness audio) to 2.9 (intended mock impoliteness video). That is, again the access to gestural information was important for detecting mock impoliteness.

\section{General discussion and conclusions}

This study set out to investigate the role of two factors that affect the listener's offline pragmatic evaluation of genuine vs. mock impoliteness, specifically, the role played by gestural and prosodic patterns together with the influence of situational/discourse context.

First, we elicited genuine and mock impolite utterances from several Catalan participants in order to check whether they exhibited systematic prosodic and gestural patterns in the two types of impoliteness, as well as to use their matched and mismatched context-utterance pairs as the materials for two separate rating experiments. The oral DCTs showed that there were some tendencies in the prosodic and gestural cues associated with the manifestation of genuine and mock impoliteness in Catalan. The audiovisual materials obtained through the oral DCTs showed that there are specific prosodic and gestural cues associated with genuine impoliteness (e.g. twice as many cases of the $\mathrm{H}+\mathrm{L}^{\star} \mathrm{L} \% \mathrm{nu}$ clear configuration than with mock impoliteness and the more frequent use of furrowed eyebrows) and mock impoliteness (e.g. such as the use of the nuclear configuration $\mathrm{L}^{\star} \mathrm{HL} \%$ and the frequent use of smiling). Thus messages uttered with intended mock impoliteness contain linguistic characteristics conventionally associated with genuine impoliteness (specifically, lexical content) but differed in their prosodic and gestural features. The two experiments in this study assessed the use of these prosodic and gestural features together with discourse context in the evaluation of genuine vs. mock impoliteness utterances. 
The results obtained from Experiment 1 revealed that when no situational prompt is provided and utterances are presented in isolation in $\mathrm{AO}$ and $\mathrm{AV}$ conditions, listeners are quite successful in their interpretation of utterances originally intended to encode genuine vs. mock impoliteness. Catalan listeners were able to perceive a difference between the intended genuine or mock impoliteness interpretation based on audio only $\left(t_{1876}=7.248, p<0.001\right)$ and audiovisual presentations $\left(t_{1876}=16.540, p<0.001\right)$, even without any discourse and situational context being provided. However, the results revealed an interesting asymmetry between the evaluation of genuine vs. mock impoliteness utterances, namely while listeners were equally successful in detecting the intended genuine impoliteness in both the $\mathrm{AO}$ and the $\mathrm{AV}$ conditions, this was not the case for mock impoliteness. When the intended mock impoliteness cases were presented in the AO condition, listeners were unsure whether to interpret the utterance as genuine or mock impoliteness (e.g. a mean perceived impoliteness rating of 3), but when the cases were presented in the AV condition they were more accurate in interpreting them as the intended mock impoliteness. We interpret this result to indicate (a) that mock impoliteness utterances display an inherent ambiguity as potentially genuinely impolite utterances and thus display a general resistance to being interpreted as mock impoliteness; and (b) that the addition of gestural cues to mock impolite utterances (i.e., the $\mathrm{AV}$ condition) is a crucial factor in their evaluation by listeners.

A similar result was replicated in Experiment 2, which provided listeners with a matched or mismatched situational/discourse context. First, as expected, Experiment 2 revealed a clear difference between the match and the mismatch conditions, in that mismatches between the discourse context and the utterance caused more uncertainty among listeners, that led their perceived impoliteness ratings to be more "neutral", i.e. on the slippery slope between genuine and mock impoliteness; conversely, a match between the discourse context and the given utterance triggered a more stark differentiation of genuine from mock impoliteness. Yet Experiment 2 also revealed a distinction between the evaluations of genuine vs. mock impoliteness utterances. As in Experiment 1, when contextual settings were congruent with the prosodic and gestural realization of the utterance (i.e., the match condition), the intended mock impoliteness utterances presented in the $\mathrm{AO}$ condition triggered uncertainty responses on the part of the listeners, while the intended mock impoliteness utterances presented in the AV condition were more accurately assessed as mock impoliteness. Moreover, when contextual settings were incongruent with the prosodic and gestural realization of the utterance (i.e., the mismatch condition), the same asymmetrical behavior was again found between the assessments of the intended genuine vs. mock impoliteness utterances. While for the intended gen- 
uine impoliteness utterances the $\mathrm{AO}$ and $\mathrm{AV}$ modalities did not affect the listeners' ratings, ratings were significantly affected by modality of presentation in the intended mock impoliteness condition: again, AV presentations favored the interpretation of mock impoliteness, regardless of the presence of a matched or mismatched context. Again, the addition of gestural cues to prosodic cues aids participants in arriving at the intended interpretation of mock impoliteness, being able to do so more easily than with just prosodic cues alone.

These findings for the mock impoliteness data play well into Haugh and Bousfield's (2012) conceptualization of mock impoliteness. In their proposal, the focus was on the evaluation of "talk" and "conduct", as well as context, by the participants in the conversation for the interpretation of mock impoliteness. This is essentially what we asked participants to do in our experiments. By providing them with both the "talk" (speech) and "conduct" (gesture) in Experiment 1, and the addition of contextual prompts in Experiment 2, they were able to evaluate the utterance as containing mock impoliteness or not. The results of the experiment show that mock impoliteness cannot be determined on the basis of "talk" alone, but rather the gestures that accompany it are likely to be key components for speakers in a conversation to evaluate as being mock impoliteness.

With regards to the adequacy results, it is interesting to note that results from the mismatch condition in Experiment 2 (mismatch condition between discourse context and target utterance) did not differ substantially from the ones in the match condition. In the mismatch condition, participants did not rate the utterances as unnatural given the discourse context; the mean ratings of adequacy for the mismatches ranged from 3 ('I doubt [that the utterance fits]') to 4 ('it fits quite well'). Notably, participants did not rate adequacy as 1 ('does not fit at all') and 2 ('not much'). Several pragmatic explanations, given by some of the participants themselves, might be relevant in understanding this pattern of results. For example, for the mismatch between a genuine impoliteness discourse context with an audio(visual) utterance intended to be mock impoliteness, one explanation could be that the speaker was using the defensive strategy of dismiss (e.g., joke) to counter genuine impoliteness (Bousfield 2007); one participant, when presented with this mismatch, said that speaker's utterance could be a sign that "they could be trying to smooth over the situation". For the mismatch between mock impoliteness discourse context with an audio(visual) utterance intended to be genuine impoliteness, one explanation could be that the speaker was using the offensive strategy of using a FTA to counter genuine impoliteness (Bousfield 2007). Another possible explanation could be, as one participant pointed out, "they could have been having a bad day and were ready to take it out on someone". Essentially, these results most 
probably indicate that listeners are continuously exposed to conversational interactions in which a set of sociopragmatic contextual factors that in principle favor some type of conduct (be it genuine vs. mock impoliteness) are combined with several conducts on the part of the speaker. After all, speakers can choose to use offensive behavior even when they are not expected to do so, and conversely they can use cooperative behavior as a defensive strategy in an extremely tense situation. This "flexibility" in the combination of contextual and linguistic triggers again argues in favor of a more dynamic and interactional approach to mock impoliteness.

This study has attempted to isolate the prosodic and gestural characteristics of genuine and mock impoliteness in an experimental setting in order to better understand how Catalan speakers both produce and recognize these specific cues to indicate one type of impoliteness over the other. This design had the intention of simulating being a third person observer who is interpreting potentially mock and genuine impoliteness utterances of unknown interlocutors, i.e., tapping into the explicit knowledge of how prosodic and gestural cues can function to signal two types of impoliteness in Catalan society. Because of the specific experimental setting chosen we were not able to control for other factors that create genuine and mock impoliteness, namely the relationship between the interlocutors and what has previously been said in the discourse, which we recognize as important in the dynamicity and interactional nature of mock impoliteness mentioned in Haugh and Bousfield (2012). As a result of choosing to focus on the message's content, i.e., "talk", and its delivery, i.e., "conduct", at the expense of other factors we cannot generalize our results to what may happen in a naturally occurring setting, (although our finding that smiles can be used to distinguish mock from genuine impoliteness, especially when the prosodic cues are similar, do support the observations of Haugh and Bousfield, 2012). For example, the oral DCT that was used to obtain our target utterances for Experiments 1 and 2 may have required participants to emphasize their intended genuine or mock impoliteness message via prosodic and gestural cues when they might have otherwise relied on more contextual cues and a shared relationship with their interlocutor. ${ }^{2}$ Future research should quantitatively examine how prosodic and gesture cues are used with other factors to achieve both types of impoliteness in more naturalistic settings and situations (e.g., spontaneous conversations, online processing, tasks that incorporate interaction patterns between several participants) as well as continuing to isolate prosodic and gestural cues in an experimental setting to provide a crosslinguistic account of mock and genuine impoliteness.

2 We would like to thank one of the anonymous reviewers for pointing this out to us. 
In sum, we argue that our experimental results provide evidence to support the view that mock impoliteness is essentially a sensitive pragmatic phenomenon that is always prone to be potentially understood as impolite behavior. As such, it needs to be continuously modulated and evaluated by participants in a conversation, who need to take into account and interactively assess sociopragmatic and discourse contextual features, as well as lexical, prosodic and gestural signals. Future research should be conducted to test if these laboratory results transfer to more naturalistic contexts.

Acknowledgements: The authors are grateful to the participants of the oral DCT production experiment (Toni Bassaganyas Bars, Sergi Casas Falcó, Sara Costa Segarra, Santiago González Fuente, Alba Milà Garcia and Laura Sánchez Manchón) and the perception experiments. We would like to thank the members of GrEP, Group of Prosodic Studies, (especially Joan Borràs-Comes, Santiago González Fuente, Maria del Mar Vanrell and Rafèu Sichel Bazin) and the audience members of the $5^{\text {th }}$ edition of the Workshop on Catalan Prosody (Barcelona, July 2013), the $2^{\text {nd }}$ UWM Symposium on Luso-Hispanic Linguistics (Milwaukee, USA, November 2013), and the $6^{\text {th }}$ Intercultural Pragmatics \& Communication Conference (University of Malta, May 2014) for comments and suggestions on earlier portions of this study. Finally, we would like to thank two anonymous reviewers for their insightful comments on an earlier draft of this paper. This research has been funded by a research grant awarded by the Spanish Ministerio de Ciencia e Innovación (FFI2009-07648/FILO), and by a grant awarded by the Generalitat de Catalunya to the Grup d'Estudis de Prosòdia (BFU2012-31995).

\section{Bionotes}

Sean McKinnon is a PhD student in the Department of Spanish and Portuguese at Indiana University - Bloomington. His research interests include Spanish and Catalan phonetics and phonology, sociolinguistics (especially in situations of language contact) and experimental pragmatics (focusing on the role of prosody and gestures).

Pilar Prieto is an ICREA Research Professor at the Department of Translation and Language Sciences at UPF (Universitat Pompeu Fabra), Barcelona, Catalunya. After obtaining a PhD in Romance Linguistics from the University of Illinois at Urbana-Champaign, she was a postdoctoral fellow at Bell Laboratories (Murray Hill, New Jersey). Since 2008, she has been the coordinator of the 
"Group of Prosodic Studies” at the Universitat Pompeu Fabra. Her main research interests focus on the description of how melody and prosody works in language and how it interacts with other types of linguistic knowledge (pragmatics, syntax), as well as on the role of prosody and gesture in the expression of linguistic meaning in interactive speech. She has edited some thematic books on these topics, and published a number of research articles, which have appeared in journals such as Journal of Phonetics, Laboratory Phonology, Journal of Cognitive Neuroscience, Journal of Pragmatics, Speech Communication, Language and Speech, among others.

\section{References}

Baayen, R. Harald, Douglas J. Davidson \& Douglas M. Bates. 2008. Mixed-effects modeling with crossed random effects for subjects and items. Journal of Memory and Language 59. 390-412.

Beckman, Mary E., Julia Hirschberg \& Stephanie Shattuck-Hufnagel. 2005. The original ToBI system and the evolution of the ToBI framework. In Sun-Ah Jun (ed.), Prosodic typology: The phonology of intonation and phrasing, 9-54. Oxford: Oxford University Press.

Bernal, María. 2008. Do insults always insult? Genuine impoliteness versus non-genuine impoliteness in colloquial Spanish. Pragmatics 18(4). 775-802.

Billmyer, Kristine \& Manka Varghese. 2000. Investigating instrument-based pragmatic variability: Effects of enhancing discourse completion tests. Applied Linguistics 21(4). 517-552.

Blum-Kulka, Shoshana, Juliane House \& Gabriele Kasper. 1989. Investigating cross-cultural pragmatics: An introductory overview. In Shoshana Blum-Kulka, Juliane House \& Gabriele Kasper (eds.), Cross-cultural pragmatics: Requests and apologies, 1-34. Ablex: Norwood, NJ.

Boersma, Paul \& David Weenink. 2008. Praat: Doing phonetics by computer (version 5.0.09). Computer program.

Bousfield, Derek. 2007. Beginnings, middles and ends: A biopsy of the dynamics of impolite exchanges. Journal of Pragmatics 39. 2185-2216.

Boxer, Diana \& Florencia Cortés-Conde. 1997. From bonding to biting: Conversational joking and identity display. Journal of Pragmatics 27. 275-294.

Brown, Penelope \& Stephen Levinson. 1987. Politeness: Some universals in language usage. Cambridge University Press: Cambridge.

Chen, Aoju, Carlos Gussenhoven \& Toni Rietveld. 2004. Language-specificity in the perception of paralinguistic intonational meaning. Language and Speech 4. 311-350.

Culpeper, Jonathan. 1996. Towards an anatomy of impoliteness. Journal of Pragmatics 25. 349-367.

Culpeper, Jonathan. 2005. Impoliteness and entertainment in the television quiz show: The Weakest Link. Journal of Politeness Research 1(1). 35-72.

Culpeper, Jonathan. 2010. Conventionalised impoliteness formulae. Journal of Pragmatics, 42. 3232-3245. 
Culpeper, Jonathan. 2011. Impoliteness: Using language to cause offence. Cambridge: Cambridge University Press.

Culpeper, Jonathan, Derek Bousfield \& Anne Wichmann. 2003. Impoliteness revisited: With special reference to dynamic and prosodic aspects. Journal of Pragmatics 35. 1545-1579.

Félix-Brasdefer, J. César. 2010. Data collection methods in speech act performance: DCTs, role plays, and verbal reports. In Alicia Martínez-Flor \& Esther Usó-Juan (eds.), Speech act performance: Theoretical, empirical, and methodological issues, 41-56. Amsterdam \& Philadelphia: John Benjamins.

Grice, Herbert Paul. 1975. Logic and conversation. In Peter Cole and Jerry L. Morgan (eds.) Speech Acts, 41-58. New York: Academic Press.

Hammerschmidt, Kurt \& Uwe Jürgens. 2007. Acoustical correlates of affective prosody. Journal of Voice 21(5). 531-540.

Haugh, Michael \& Derek Bousfield. 2012. Mock impoliteness, jocular mockery and jocular abuse in Australian and British English. Journal of Pragmatics 44. 1099-1114.

Hidalgo Navarro, Antonio. 2009. Modalización (des)cortés y prosodia: estado de la cuestión en el ámbito hispánico. Boletín de Filología, Tomo XLIV, 1. 161-195.

IBM Corporation. 2011. IBM SPSS Statistics 20.0.

Lampert, Martin D. \& Susan M. Ervin-Tripp. 2006. Risky laughter: Teasing and self-directed joking among male and female friends. Journal of Pragmatics 38. 51-72.

Leech, Geoffrey. 1983. Principles of Pragmatics. London: Longman.

Lin, Hsin-Yi, Kwock-Ping John Tse \& Janice Fon. 2006. An acoustic study on the paralinguistic prosody in the politeness talk in Taiwan Mandarin. Proceedings from ISCA Tutorial and Research Workshop on Experiment Linguistics. Athens, Greece.

McNeill, David. 1992. Hand and mind: What gestures reveal about thought. Chicago: University of Chicago Press.

Mugford, Gerrard. 2013. Foreign-language users confronting anti-normative politeness in a Mexican university. Intercultural Pragmatics 10(1). 101-130.

Murray, lain R. \& John L. Arnott. 1993. Toward the simulation of emotion in synthetic speech: A review of the literature on human vocal emotions. Journal of the Acoustical Society of America 93(2). 1097-1108.

Nadeu, Marianna \& Pilar Prieto. 2011. Pitch range, gestural information, and perceived politeness. Journal of Pragmatics 43. 841-854.

Ofuka, Etsuko, J. Denis McKeown, Mitch G. Waterman \& Peter J. Roach. 2000. Prosodic cues for rated politeness in Japanese speech. Speech Communication 32. 199-217.

Pierrehumbert, Janet. 1980. The phonology and phonetics of English intonation. PhD dissertation, MIT, published 1988 by IULC.

Prieto, Pilar. 2014. The intonational phonology of Catalan. In Sun-Ah Jun (ed.). Prosodic typology 2. The phonology of intonation and phrasing, 43-80. Oxford: Oxford University Press.

Prieto, Pilar, Joan Borràs-Comes, Susagna Tubau \& M. Teresa Espinal. 2013. Prosody and gesture constrain the interpretation of double negation. Lingua 131. 136-150.

Quené, Hugo \& Huub van der Bergh. 2008. Examples of mixed-effects modeling with crossed random effects and with binomial data. Journal of Memory and Language 59. 413-425.

Stenström, Anna-Brita \& Annette Myre Jörgensen. 2008. A matter of politeness? A contrastive study of phatic talk in teenage conversation. Pragmatics 18(4). 635-657. 


\section{Appendix}

Discourse Contexts of the oral DCT production task (see Section 2.1.2)

\begin{tabular}{lll}
\hline oral DCT & Genuine Impoliteness & Mock Impoliteness \\
\hline ODCT 1 & $\begin{array}{l}\text { Catalan: Després d'un desastrós tall de } \\
\text { cabell, estàs ben empipat amb el teu }\end{array}$ & $\begin{array}{l}\text { Catalan: Després d'un desastrós tall de } \\
\text { cabell, estàs ben empipat amb el teu }\end{array}$ \\
nou pentinat. El perruquer t'ha deixat & nou pentinat. El perruquer t’ha deixat \\
només amb un dit de cabell. Quan ar- & només amb un dit de cabell. Quan ar- \\
ribes a casa, et mires al mirall i comen- & ribes a casa, et mires al mirall i comen- \\
ces a riure perquè et sembla que ha & ces a riure perquè et sembla que ha \\
quedat totalment ridícul i no hi ha ma- & quedat totalment ridícul i no hi ha ma- \\
neres d'arreglar-ho. Aquesta nit et reu- & neres d'arreglar-ho. Aquesta nit et reu- \\
neixes en un restaurant amb el grup de & neixes amb els teus millors amics i \\
pàdel del gimnàs. Hi ha persones que & saps que els encantarà veure't amb \\
coneixes i d'altres que no has vist mai. & aquest pentinat tan alternatiu. Quan ar- \\
Quan arribes veus que hi ha un noi, & ribes veus que en Pau comença a riure i \\
que sembla el graciós del grup, que & et diu: \\
comença a riure i et diu: & “Què, t’han passat el tallagespes pels \\
“Què, t'han passat el tallagespes pels & cabells, avui?” \\
cabells, avui?” i continua rient. Tu t'em- & i continua rient. Tu el contestes en to \\
pipes molt. & de broma i li dius que se'n vagi a la \\
Ara digue-li que se'n vagi a la merda. & merda.
\end{tabular}

English: After a disastrous haircut, you are very angry about your new hairstyle. The stylist left you with only a little bit of hair. When you arrive home, you look in the mirror and begin to laugh because it looks totally ridiculous and there is not a way to fix it. That night you are going to meet up with the gym paddle group at a restaurant. There are some people that you know and others that you have never seen before. When you arrive, you see a boy, who appears to be the funny guy of the group, start to laugh and he says to you: "What, did a lawnmower cut your hair?" and he continues to laugh. You are very annoyed.

English: After a disastrous haircut, you are very angry about your new hairstyle. The stylist left you with only a little bit of hair. When you arrive home, you look in the mirror and begin to laugh because it looks totally ridiculous and there is not a way to fix it. That night you are going to meet up with your best friends and you know that they will love to see you with your new alternative haircut. When you arrive you see Pau start to laugh and he says to you: "What, did a lawnmower cut your hair?" and he continues to laugh. You jokingly respond by telling him to go to hell.

Now tell him to go to hell.

ODCT 2 Catalan: Són les sis de la tarda i ets a la biblioteca acabant un treball de final de curs. Has estat a la biblioteca sis

Catalan: Són les sis de la tarda i ets a la biblioteca acabant un treball de final de curs. Has estat a la biblioteca sis 


\begin{tabular}{l}
\hline oral DCT \\
\hline Genuine Impoliteness \\
hores sense fer cap descans i encara no \\
vas ni per la meitat del treball. El tre- \\
ball s'ha d'entregar abans de mitjanit i \\
estàs corrent per acabar-lo a temps. Al- \\
ces la vista veus un company de classe \\
amb el qual no tens gaire bona relació, \\
sempre t’ha semblat un pilota amb els \\
professors. S’apropa al teu pupitre i \\
després de saludar-te et diu rient: \\
“Què, encara no has acabat el treball? \\
Jo el vaig entregar ahir i crec que trauré \\
un 10 !”. A tu et molesta molt i no vols \\
sentir-lo més. \\
Ara digue-li que agafi la seva puta feina \\
i que se la foti al cul.
\end{tabular}

English: It's six o'clock in the afternoon and you are at the library finishing up a final paper for a course. You have been at the library for six hours without a break and you are not even half way done with your work. The paper has to be turned in before midnight and you are rushing to finish it on time. You see a classmate who you don't have a good relationship, he always seems to be a suck up to the professors. He comes over to your desk and after greeting you he says, laughing, "What, you still haven't finished the paper? I turned it in today and I'm sure I'm going to get a 10 !". He really annoys you and you don't want to listen to him any more. Now tell him to take his work and shove it up his ass.

ODCT 3 Catalan: Estàs conduint cap a casa després d'un llarg dia a la feina. El trànsit va molt lent i t'has trobat un embús. $\mathrm{Hi}$ ha moltes botzines sonant i t'està agafant mal de cap. De sobte, un cotxe surt davant teu d'un pàrquing, et talla bruscament $\mathrm{i}$ arrenca a córrer, passant

\section{Mock Impoliteness}

hores sense fer cap descans i encara no vas ni per la meitat del treball. El treball s'ha d'entregar abans de mitjanit i estàs corrent per acabar-lo a temps. Alces la vista i veus que s'apropa el teu millor amic de classe, en Genís. Ell sempre treu pitjor notes que tu i sempre en feu broma. S'apropa al teu pupitre i després de saludar-te et fa una brometa, abraçant-te: "Què, encara no has acabat el treball? Jo l'acabo d'entregar i segur que tindrà millor nota que el teu, com sempre!" i continua rient.

Tu el contestes en to de broma i li dius que que agafi la seva puta feina i que se la foti al cul.

English: It's six o'clock in the afternoon and you are at the library finishing up a final paper for a course. You have been at the library for six hours without a break and you are not even half way done with your work. The paper has to be turned in before midnight and you are rushing to finish it on time. You see one of your best friends from class, Genís. He always gets worse grades than you and you guys always joke around. He comes over to your desk and after greeting you he makes a little joke, while hugging you, "What, you still haven't finished the paper? I turned it in today and I'm sure I'm going to get a 10 !" and he continues to laugh.

You jokingly tell him to take his work and shove it up his ass.

Catalan: El teu millor amic, en Lluís, t'ha vingut a buscar a la feina i et porta a casa després d'un llarg dia. El trànsit va molt lent i us heu trobat un embús. Hi ha moltes botzines sonant i t'està agafant mal de cap. Amb el teu amic sempre feu broma perquè condueix de 


\begin{tabular}{l}
\hline oral DCT \\
\hline Genuine Impoliteness \\
el semàfor gairebé en vermell. Tu estàs \\
molt empipat, què li diries en veu alta? \\
Ara digue-li que hòstia puta, que miri el \\
cony de carrer quan condueix.
\end{tabular}

English: You are driving home after a long day at work. Traffic is going very slowly and you are stuck in a jam. There are many horns honking and you're starting to get a headache. Suddenly, a car leaves the parking garage in front of you, sharply cutting you off and he accelerates quickly, going through the yellow light. You are very angry, what would you yell at him? Now say goddammit, look at the fucking road when you're driving.

\section{Mock Impoliteness}

forma molt agressiva. De sobte, veu un forat a l'embús i talla bruscament el cotxe de l'esquerra i arrenca a córrer, passant el semàfor gairebé en vermell. Tu dius en to de broma que hòstia puta, que miri el cony de carrer quan condueix.

English: Your best friend, Lluís, has come to pick you up from work after a long day. Traffic is going very slowly and you are stuck in a jam. There are many horns honking and you're starting to get a headache. With your best friend you guys are always joking around because he is a very aggressive driver. Suddenly, he sees a hole in the traffic jam and he abruptly cuts off the car to your left, quickly accelerating and going through the yellow light.

You jokingly say goddammit, look at the fucking road when you're driving.

Catalan: Has convidat el teu grupet d'amics a fer unes copes a una discoteca. Sempre feu broma perquè hi ha un amic vostre, en Joan, que és una mica maldestre i sempre li esteu fent broma. Aquella nit, després d'unes quantes copes, vessa sense voler la cervesa pel terra de la discoteca.

Ara digue-li, en to de broma, que miri el puto terra.

English: You have invited your best group of friends to go out to a dance club to drink. You guys are always joking around because you guys have one friend, Joan, who is pretty awkward and you guys always make fun of him. During the night, after a couple of drinks,
English: A group of your new roommate's friends arrive at your house to drink a little bit before going out for the night. You don't know his friends very well, but there is one, Carles, who you don't like too much because he appears to be pretty rude. During the night, aft- 


\begin{tabular}{|c|c|c|}
\hline oral DCT & Genuine Impoliteness & Mock Impoliteness \\
\hline & $\begin{array}{l}\text { er a couple of drinks, he begins to yell } \\
\text { and spill beer all over the floor again } \\
\text { and again. There's a moment where he } \\
\text { spills his beer all over the floor of the } \\
\text { dining room. } \\
\text { You are very angry and now tell him to } \\
\text { look at the fucking floor. }\end{array}$ & $\begin{array}{l}\text { he spills some of his beer on the floor } \\
\text { of the dance club. } \\
\text { Now tell him, jokingly, to look at the } \\
\text { fucking floor. }\end{array}$ \\
\hline \multirow[t]{2}{*}{ ODCT 5} & $\begin{array}{l}\text { Catalan: Heu quedat amb els amics } \\
\text { d'un company de pis per anar al cine- } \\
\text { ma. No els coneixes gaire, però n'hi ha } \\
\text { un que sempre es fa el graciós, en Ma- } \\
\text { teu. Mentre demanen les crispetes tu } \\
\text { te'n vas al lavabo. Quan tornes tens } \\
\text { una mica de paper de vàter enganxat a } \\
\text { la sabata. Quan estàs arribant cap al } \\
\text { grup en Mateu et crida i et diu rient: } \\
\text { "Què, has ressuscitat una mòmia? Ets } \\
\text { un brut, tio" } \\
\text { Tu estàs molt emprenyat. Ara digue-li } \\
\text { que calli d'una puta vegada }\end{array}$ & $\begin{array}{l}\text { Catalan: Has quedat amb els teus mil- } \\
\text { lors amics per anar al cinema. Mentre } \\
\text { dos demanen les crispetes tu te'n vas } \\
\text { al lavabo. Quan tornes tens una mica } \\
\text { de paper de vàter enganxat a la sabat i } \\
\text { et trobes amb el teu millor amic esper- } \\
\text { ant-te, que et diu rient i fent broma: } \\
\text { "Què, has ressuscitat una mòmia? Ets } \\
\text { un brut tio" } \\
\text { Tu li contestes fent broma i li dius que } \\
\text { calli d'una puta vegada }\end{array}$ \\
\hline & $\begin{array}{l}\text { English: You and your roommate are } \\
\text { meeting with some of his friends to go } \\
\text { to the movies. You don't know them } \\
\text { very well, but there is one guy who is } \\
\text { the funny guy of the group, Mateu. } \\
\text { While they are getting some popcorn } \\
\text { you go to the bathroom. When you re- } \\
\text { turn you have a little bit of toilet paper } \\
\text { stuck to the bottom of your shoes. } \\
\text { When you approach the group Mateu } \\
\text { says to you, laughing: "What, did you } \\
\text { resurrect a mummy? Man, that's nasty." } \\
\text { You are very angry. Now tell him to shut } \\
\text { the fuck up. }\end{array}$ & $\begin{array}{l}\text { English: You are meeting with your best } \\
\text { friend to go to the movies. While two of } \\
\text { them are getting some popcorn you go } \\
\text { to the bathroom. When you return you } \\
\text { have a little bit of toilet paper on the } \\
\text { bottom of your shoe and go over to } \\
\text { your best friend, who is waiting for you, } \\
\text { and he says to you laughing and mak- } \\
\text { ing a joke: } \\
\text { "What, did you resurrect a mummy? } \\
\text { Man, that's nasty." } \\
\text { You jokingly respond to him by telling } \\
\text { him to shut the fuck up. }\end{array}$ \\
\hline
\end{tabular}


Copyright of Journal of Politeness Research: Language, Behavior, Culture is the property of De Gruyter and its content may not be copied or emailed to multiple sites or posted to a

listserv without the copyright holder's express written permission. However, users may print, download, or email articles for individual use. 